\title{
»Ustvarjalni duh metafizične naravnanosti«
}

\section{'A Creative Spirit of a Metaphysical Attitude'}

Prejeto: 17. avgusta 2008

Sprejeto: 5. septembra 2008

Ključne besede: Uroš Krek, skladateljska poetika, kompozicijski načrt, interakcija estetika-kompozicijska sredstva

\section{IZVLEČEK}

In memoriam Urošu Kreku (1922-2008), klasiku novejše slovenske glasbe, avtorju obsežnega in dragocenega orkestralnega, komornega, klavirskega in zborovskega opusa ponuja v premislek oporne točke in premise njegovega skladateljevanja. Analizira njegovo duhovno osišče, temeljni odnos do glasbe in vrsto strateških odločitev, ki pogojujejo fiziognomijo njegove kompozicijske tehnike. Umešča ga pogojno v področje neoklasicističnega ludizma in avtonomije glasbe ter obravnava avtorjev odnos do modernizma, novega in tradicije, do zgodovinskega in ljudskega glazbenega izročila.

\author{
Received: 17th August 2008 \\ Accepted: 5th September 2008
}

Keywords: Uroš Krek, compositional poetics, compositional plan, interaction: aesthetics - compositional means

Abstract

In memoriam Uroš Krek (1922-2008), a classic of newer Slovene music and composer of an extensive as well as precious orchestral, chamber, piano, and choral output, discusses bases and premises regarding his composing. It analyses the spiritual axis his strategic decisions that conditioned the physiognomy of his compositional technique. Conditionally, the article gives him a place in the sphere of neoclassical ludism and the autonomy of music, at the same time dealing with the composer's relation to modernism, novelties and tradition, and to the historical and folk music heritage.

Dokončno sklenjen življenjski in ustvarjalni krogotok skladatelja akademika Uroša Kreka, velike osebnosti slovenske glasbe 20. stoletja, vabi k spoštljivem poklonu njegovemu delu in poskusu premisleka njegovega bivanja $v$ glazbi. Značajske poteze nepotvorjene tolerance do okolja, vedra in topla odprtost do sočloveka, aristokratska, omikana drža izobraženca - ti temelji mojstrove osebnosti so seveda zarisovali tudi okvir njegovega skladateljevanja, sodelovali pri odločitvah in usmeritvah. Njegovo delo je namreč potekalo $\mathrm{v}$ glasbenem kontekstu, ki taki človeški in intelektualni 
podstati ni bil pisan na kožo in ga je sam obzirno opredelil kot zapleteno duhovno ozračje. ${ }^{1}$

V času splošnega propadanja vrednosti, ko je umetnost izgubljala svojo filozofskoestetsko osnovo (ki je skozi stoletja fungirala kot urejujoča moč sveta), v času zatona izobražene družbe z njeno samoumevno estetsko kulturo je Uroš Krek očitno vztrajal na področju estetskega in v njem videl pribežališče ideje humanega; razumel ga je kot nepogrešljivi del tistega spoznanja v katerem se človek artikulira v celovitosti svojih čutnih, emocionalnih in kognitivnih zmožnosti. Čutil je potrebo po širokem obzorju in hkrati trdnem lastnem duhovnem središču, ki ne pozna nietzschejanskega bivanja "zunaj dobrega in zla«. Klasična izobrazba, slavistična in kompozicijska diploma, trdna zasidranost v domačih tleh in mentaliteti, opredelitev za lepo kot gonilno moč umetnosti, zaupanje v ustvarjalno potenco, nagib, domislek in vizijo - to so bile oporne točke na katerih je zgrajena Krekova glasbena zapuščina. Tej dostojanstveno-resni drži, ki priča o odgovornosti do glasbenega dela, je njegova narava dodajala tudi vedro igrivost (le-ta je zapuščala jasne sledove v domiselni, včasih skoraj neugnani kombinatoriki glasbenih prvin) kot eno od plati glasbe, ki jo je imel za samostojno kategorijo estetskega uživanja. Mnoge Krekove danes že klasične skladbe, ki pripadajo temeljni zakladnici novejše slovenske glasbene literature (spomnimo, iz bogatega orkestralnega opusa, vsaj na antologijsko Sinfonietto, 1951, Mouvements concertans, 1955, Inventiones ferales za violino in godala, 1963, Sinfonio per archi, 1973) izhajajo iz uravnovešene soigre refleksije in občutenja samega sebe na temeljni matrici estetskega. V časih, ko se je položaj estetske izkušnje kot razvojno sposobnega čutnega fenomena bistveno spreminjal in se je vse bolj oddaljeval od svoje humanistične podstati, ko je diskurzivno občasno močno in zapovedovalno prekašalo čutno ter so se v glasbenem svetu porajali različni leseni jeziki (G. Orwell) je Krek vztrajal pri univerzalni humanistični orientacijski točki kot nepogrešljivi opori za oblikovanje kritične zavesti in vsaj minimalnega skupnega imenovalca za sporazumevanje z občinstvom. Čeprav pri komponiranju ni mislil na občinstvo je imel vendar v sebi neprestano človeka, ki bo nekočposlušal te moje note. Torej: ne samozadostnost ustvarjalnega dejanja, temveč poslanstvo, potreba po prenosu lastne ustvarjalne energije in doseženega cilja drugemu, upanje, da njegova glasbena govorica zmore doseči poslušalca in ga voditi skozi različna območja doživljajskih odtenkov.

Morda je v naravi ustvarjalnosti, da njeni cilji, tudi če so ozaveščeni in celo oznanjeni, največkrat ostajajo zakriti. Uroš Krek se v časih manifestnih opredeljevanj za »novo« ni pretirano oziral na modo, na različna umetnostna gibanja in ideologije; obžaloval je razkrojenost družbe svojega časa in tolikšno diferenciacijo v glasbi, ki je pripeljala do tega, da se glasbeniki ne razumejo več med seboj. Okoliščine je prepoznaval, ugotavljal, vendar je optimistično verjel, da družba vendar premore neki normativ za urejanje glasbenih vrednot. Za svoje lastno skladateljsko delo si je take normative postavljal sam, ne glede na trenutno privlačne modne skrajnosti pred katerimi pa se tudi ni zapiral z odklonilnimi ali obrambnimi zasloni. In čeprav je menil da ni genialno navdahnjen in da njegov opus morda ni tako enovit kot naj bi bil, je pravzaprav na svoji skladateljski

\footnotetext{
Vse navedbe iz naslednjih pogovorov s skladateljem: Marijan Zlobec: Komponiranje - aristokratsko opravilo, Delo (Sobotna priloga), 7. 2. 1992; Marjan Kunej: Kjer sem, naj bo veliko ustvarjalnega dela, Večer, 7. 2. 1992; Milena Vehovar: Glasba je zame vera, svetovni nazor, Slovenec, 22. 6.1996.
} 
poti izkazoval doslednost in stanovitnost koraka. Zasledujoč vidike in izglede aktualnih glasbenih idej in gibanj okoli sebe, se je očitno zavedal, da se tam, kjer naj se ideje sprevračajo v umetnost, spet začenja individualna svoboda pri odločanju in nepredvidljivost izidov. Arnold Schönberg bi dejal, da pravi skladatelj ne more ustvariti ničesar drugega, razen to, $k$ čemur ga silita njegova narava in razvoj.

Krekova narava je nalagala premišljenost, red, jasnost, razvoj pa je potekal v odmiku od kompozicijske šole L. M. Škerjanca proti predvsem neoklasicističnim modelom, ki so v petdesetih letih močno prevevali naš glasbeni prostor. Ne glede na dvomljivost in nezadostno utemeljenost termina kot morebitne slogovne opredelitve, je polje določil, povezanih z značilnostmi skladateljskih poetik, ki jih uvrščajo med neoklasicistične, tako blizu Krekovi poetiki, da je tudi sam potožil: škoda, da je obdobju te slogovne naravnanosti bil odmerjen tako kratek čas! Vendar, če naj bi za neoklasicistične imeli različne fermentacije eksperimentalnih dosežkov in načelno opozicijskost do eksperimentalnih pretiranosti nasploh, pa ideal estetske enostavnosti in oblikovne jasnosti, dalje stilistično odprtost in palimpsestnost, ki sta se kasneje tako dobro stikali s postmodernistično sproščenostjo v odnosu do različnih plasti izročila in postopanja z izbranimi modeli potem je taka opredelitev ostala Krekova stalnica, ne glede na spremembe od skladbe do skladbe, oz. glede na konkretne »delovne načrte« vsake posamezne.

Ti »delovni načrti« pa odkrivajo pravo naravo Krekove umetnosti kompozicije. Očitna je bila želja po čim večji artikuliranosti in enovitosti, hkrati pa tudi individualiziranosti tonskega stavka. Kljub temu da bi globlji analitični pogled (nič drugače kot pri vsakem "pravem«skladatelju) tudi pri Kreku ugotovil obstoj nekakšne temeljne matrice (avtor jo je razumel kot danost po sebi, ki jo je bilo treba "napolniti« z invencijo), je očitno zasledoval misel, da tudi sama zasnova mora biti invencija, ki angažira celotno umetnikovo originalnost. Skušal pa se je izogniti sprevračanju glasbenih idej v krut sistem, saj mu je »navidezni nered «, ki pravzaprav izpričuje svobodno gibanje v zarisanem okviru, predstavljal spodbujevalno gonilo. Zavedal se je pomena improvizacijskosti kot prvega izhodišča domisleka in potrebe po trdni kompozicijski logiki v njegovi nadaljnji razdelavi in organizaciji. V tej logiki prevladuje igra analogij in kontrastov, skrbno delo s kombiniranjem prvin, »subtilno razgrinjanje različnega z enakim«, "premene poudarkov med prvinami«(L. Stefanija). In če je kontrast praviloma enoznačen, neposreden in pogojen s semantično (občasno celo »oznanjeno« zunajglasbeno) intenco, ki tudi Kreku ni bila tuja, so analogije zagotovilo enovitosti. Krek je z njimi operiral virtuozno, na sledi prepričanja, ki ga je delil s Stravinskim, namreč, da je "glasba toliko bolj krepka in močna kolikor je bolj sposobna ubraniti se zapeljivosti raznoterosti. Kar izgublja s sumljivimi bogastvi, pridobi z resnično konsistenco.«

»Sumljiva bogastva« za Uroša Kreka niso bila preveč zapeljiva. Bil je radoveden, vendar izbirčen, ker modernost zanj ni bila temeljna vrednost, ki bi pogojevala vse ostale. Ni zasledoval predvsem težnjo po spreminjanju, prej tisto po umirjanju turbulenc. Komunikacijo z različnimi glasbenimi sistemi (ki se je občasno ostrila v ludično transkribcijo modelov) je umeval prej kot izkazovanje veščine, na način, ki ga razume nekdanji pojem ars, torej kot stik veščine in umetnosti. Obrtna sposobnost naj se podredi živemu tkivu. V inovativni gesti ni priznaval vidika razvrednotenja obstoječih vrednosti, še posebej tuje mu je bilo ovrednotenje profanega, neuglajenega, grobega. Dovolj je bilo 
prevrednotenje znanega, ki naj ostane prepoznavno. Tudi ta drža je izhajala iz umevanja skladateljskega dela kot izražanja lastnih občutij in pričevanja o občutljivosti človeka nasploh, iz pojmovanja glasbe kot vere, svetovnega nazora; in v osnovi pripadanja tistim idealom glasbe, ki jih je realiziral ustvarjalni duh metafizične naravnanosti. Sledi torej impulzom ideje in izbranega gradiva, določa svoje omejitve, ki so hkrati opora in izziv, se veseli domiselnemu tehničnemu delu pri izdelavi logične, dosledne, disciplinirane glasbene fakture.

Iz takega odnosa do skladateljskega dela, iz potrebe po omejitvah izhaja tudi Krekov odnos do starega, znanega, tradicije. Bolj ga zanima dialog z znanim, kot pa inovacija, kateri je vse odprto in dostopno in katere morebitna "pravila" pravzaprav kličejo po kršitvah. Novo in enkratno najdeva v domisleku, zasnovi, izpeljavi, učinku svojega, po sebi enkratnega kompozicijskega predloga. Zato je večinoma ostajal v okvirih tradicije zvrsti, preizkušenih oblikovnih obrazcev, ki jih je treba "napolniti« z novo duhovno vsebino in realizirati s pomočjo izbrušene tehnike.

Tradicija pa je zanj tudi zgodovinsko glasbeno izročilo, enako kot ljudsko. Obe izročili je zase odkrival, z naporom in skrbnostjo (v petdesetih letih kot glavni urednik glasbenega programa Radio Ljubljane, v šestdesetih kot znanstveni sodelavec v Glasbeno-narodopisnem inštitutu, kjer je zbirki prispeval približno dvajset tisoč transkripcij gradiva, zabeleženega na terenu). V obeh je zaznaval lastne korenine in prepoznaval svojo muzikalično bit. Zavedal se je torej sedanjosti, ki je v bistvu funkcija preteklosti. In se močno upiral novemu analfabetizmu. (Tudi kot pedagog, ki je v svojem kompozicijskem razredu izobrazil vrsto danes pomembnih, priznanih skladateljev, je zastopal poklicno kompetentnost, obrtniško izurjenost in skrajnjo toleranco do njihovih lastnih izbranih poti.)

Med orodja Krekove skladateljske strategije torej sodi že omenjena identifikacija z intonacijami, načini strukturiranja in izrazno vsebino ljudskega izročila. Zveza z njimi je zanj bistvenega pomena. Ozavestil je ta pomen, se mu prepustil in mu dovolil inicialne spodbude za preoblikovanja in prevrednotenja $v$ artificialnih preoblekah. Vzoroval se je pri Béli Bartóku in ga pogosto citiral glede na pomen izvirnega, ljudskega gradiva za umetniško glasbo. Motivične celice, pa tudi cele ljudske napeve je včasih komajda razlikoval od lastnih domislekov, tako globoko so bili ti prvi zasidrani v njegovem občutenju glasbenega. Enako kot Bartók pa je v istovetenju ljudskega in lastnega videl kratkomalo naravno danost glasbeno občutljivega človeka določenega podnebja. (Le-ta po njegovem mnenju sodi v človekovo muzikalično dušo. O njej je želel izvedeti kaj več, odtod njegovo napotilo na primerjalne študije folklore.)

Šele v delu z glasbenim gradivom (zdaj že katerimkoli) pa je prepoznaval pravo bistvo komponiranja. Tisto, ki utemeljuje skladateljevo identiteto. Iskati jo je v tem kako vtise, doživetja, izbrano gradivo oblikuje, kako realizira svoje spekulativno hotenje, kakšen red vzpostavlja v svojih strukturah, kako sledi napetostnim energijam gradiva, kako se obnaša do "prisile gradiva«, o kateri govori A. Schönberg, ko utemeljuje svoj pojem glasbene logike. V takšnih postopkih, vzpostavitvi pravil in ravnanju po njih se je dogajala Krekova umetnost. V intimi in osami delavnice. V globoki koncentraciji in veselju do dela. Vedel je, kako je treba nekaj narediti, da zveni dobro; bilo je to znanje »od znotraj«, glasbeno znanje. Tu je zmogel izpričati domiselnost svoje kombinatorike, svojo 
konstruktivistično spretnost, pokazati, kaj premore na področju glasbeno avtonomne umetniške igre. Jasno je razporejal gradivo, "premerjal « dolžine in odnose, gradil mikro in makro variantne povezave, spreminjal podobo glasbene geste, iznajdeval pravila, ovire, omejitve. In nadzoroval sam sebe.

Superiorna, in hkrati skromna distanciranost do sebe samega - zaznavali in ugotavljali so jo mnogi - je povsem v soglasju s takšno držo. Govor o samem sebi, romantično, vihravo, samovšečno razkrivanje intime, ne sodi med osebnostne in glasbene značilnosti Krekovega glasbenega lika. Ni čutil potrebe po pretiranem psihologiziranju. Objektivizirani, rahlo zastrti individualizem modernega časa mu je bil pri tem v oporo. Zadržanost, opazovanje od zunaj, vstopanje v različne vsebinske in doživljajske položaje, izstopanje iz njih, opazovanje, nevsiljivost, odmaknjenost. Celostna podoba, harmonična in uravnovešena.

Vsako umetniško delo je svojevrstno šifrirano sporočilo, oporočno zapuščeno Drugemu, ki naj bi ga ustrezno sprejel in razumel. Prav to je bila Krekova najintimnejša želja: uganili naj bi namen in vsebino njegovih sporočil, jih sprejeli in zadržali v spominu. Vtisniti se slovenskemu narodu v spomin s svojimi skladbami, to si je zaželel ob sprejemu Prešernove nagrade za življenjsko delo leta 1992. V času, v katerem vse glasnejša postajajo razmišljanja o koncu umetnosti, se up, da Krekove glasbene oporoke vendarle ne bodo izneverjene, opira na Rilkejevo misel, da »umetniška dela predstavljajo neskončno samoto in se do njih najtežje predira s kritiko. Edinole ljubezen jih lahko razume, obdrži na življenju in zmore biti pravična do njih.« Upati je, da takšno ljubezen premoremo.

\section{SuMmary}

The large and precious orchestral, chamber, piano, an choral output of Uroš Krek (1922-2008), a classic of newer Slovene music, came into being in circumstances that he himself characterized as $a$ complicated spiritual environment which, taking into account his tolerant, humanly warm character and aristocratic, intellectually accomplished points of departure, was certainly not his cup of tea. In times, during which the arts losing their philosophical-aesthetic basic, Krek preserved in the field of the aesthetic, to his thinking, a retreat for the idea of the humane. The aesthetic is an indispansible part of man's recognizing as well as articulating his sensual, emotional, and cognitive abilities in their entirety. Classical education, Slavonic and compositional studies, firm embeddedness in his native soil and mentality, his siding with the beautiful as the driving force of art, and his trust in creative power, inventiveness, visions, and impulses, all these were the pillars of Krek's musical legacy.

This rather serious poise is complemented by playfully cheerful ease that can be detected in the composer's inventive, at times irrepressible combinations of musical elements, since for him music is an independent category of aesthetic pleasure. Many of his nowadays already classical compositions (e.g. the orchestral Sinfonietta (1951) or Mouvements concertants (1955), Inventiones ferales for violin and strings (1964), Sinfonia per archi (1973)) result from a balanced interplay between reflecting on as well as perceiving oneself on the ultimate matrix of the aesthetic. And more: the creative act is not self-sufficient. Krek considers it a mission, a transfer of one's own creative energy to the Other, i.e. the listener, with the aim of leading him throught various spheres and niceties of experience.

Constants of Krek's music are prudence, clarity, and order, whereas his development (after leaving L. M. Škerjanc's compositional school) led him towards neoclassicistic models, and, later, to postmodern ease in dealing with various layers of tradition and chosen models. Individual 'work schedules' of his compositions revel further characteristics of Krek's writing: the wish to achieve the highest possible degree of articulated unity, as well as individuality of the texture, evade the (even with him detectable) possibility of the compositional matrix's turning into a straightjacket, and to be aware of the improvisatory nature of the original idea that, in its further development, should be 
followed by firm compositional logic, in which elaborated combinations of elements as well as interactions between analogies and contrasts prevail. In his work Krek is always inquisitive, through fastidious, since modernity as such has no basic value everything else might be conditioned by. Communication between various musical systems is to be understood as a revelation of skill in the sense of the bygone notion of arts, i.e. in constant contact with art, since, to Krek, music is faith or rather Weltanschauung. Actually, Krek is after those ideals of music that have been realized by the creative spirit of metaphysical attitudes.
Among the means of his compositional strategy one should also mention his bartókianly understood identification with information, ways of structuring, and the expressive content of folk music tradition. The equating of folklike with personal the composer appears to consider as an actual fact inherently present in a musically sensitive person that belongs to a certain milieu.

The composer's most intimate wish was to impress himself - through his compositions - on the memory of the Slovene man. One can only hope that we do enjoy Rilke's 'understanding through love' which might keep Krek's work everlastingly alive. 